\title{
MENIMBANG PEMIKIRAN MASDAR FARID MAS'UDI TENTANG DOUBLE TAXS (ZAKAT DAN PAJAK)
}

\author{
Taufiq Hidayat, IAIN Walisongo Semarang
}

\begin{abstract}
The revenue sources of Country in the early days of Islam, such as zakat and taxes they are jizyah, kharaj, max (customs), and 'usyr (export-import customs) and also ghanimah and fai' (spoils of war and confiscated items). For Muslims in Indonesia,in addition they have to pay taxes to the state that include property tax,commercial goods tax, goods consumption tax, fiscal when traveling abroad, income tax, etc., they also have to pay zakat that include zakat fitrah and zakat property. Thus, Indonesian Muslims have to bear double taxs, they are taxation and zakat. This academic anxiety felt by one of the Indonesian Muslim intellectual, Masdar Farid Mas'udi. Departing from that academic anxiety Masdar then pour his fresh ideas and even controversial, especially on the issue of double taxs.
\end{abstract}

Keyword: zakat dan pajak.

\section{Pendahuluan}

Zakat dalam Islam tidak hanya berdimensi ibadah, tetapi juga berdimensi sosial. Dengan kata lain, zakat tidak hanya mengenai urusan antara seorang hamba dengan Tuhannya, tetapi juga urusan antar sesamanya. Dalam bahasa agama, zakat berfungsi sebagai penyuci diri (tuthabhirohum) dan penyuci hartanya (wa turakkibim biha), sedangkan dalam ranah sosial, zakat berfungsi untuk mensejahterakan rakyat yang miskin dan fakir.

Lebih dari itu, pada masa awal Islam, zakat berfungsi sebagai sumber utama anggaran pendapatan dan belanja negara (APBN), maka tidak heran, kalau khalifah Abu Bakar mengeluarkan kebijakan keras untuk memerangi dan menumpas orang-orang murtad, karena mereka berarti tidak lagi membayar zakat dan kalau tidak membayar zakat, maka sumber utama negara akan 
berkurang banyak yang akan mengakibatkan naiknya inflasi dan munculnya resesi ekonomi dan pada akhirnya negara bisa collaps dan ambruk.

Berdasarkan peristiwa yang terjadi pada masa Abu Bakar tersebut dapat dipahami bahwa zakat dikelola oleh negara dan menjadi sumber APBN di samping sumber yang lainnya seperti pajak yang meliputi jisyah, kharaj, maks (bea cukai), dan 'usyr (bea ekspor-impor) dan juga ghanimah dan fai' (barang rampasan perang dan barang-barang sitaan). Sejarah Islam awal juga menegaskan bahwa tidak ada double taxs yang harus dipikul oleh umat Islam. Mereka hanya diwajibkan membayar zakat kepada negara, sementara umat non Muslim yang tinggal di negara Islam mereka harus membayar pajak jisyah sebagai jaminan keamanan bagi mereka, pajak kharaj dikarenakan kepemilikan mereka atas tanah pada zaman dahulu yang kemudian diambilalih oleh Islam dan kemudian menjadi hak milik negara Islam (masa Umar ibn Khattab), sementara mereka hanya memiliki hak pakai, dan bahkan ketika mereka panen, mereka juga masih dikenakan pajak 'usyur (tanaman; pajaknya 10\% kalau tadah hujan dan 5\% kalau memakai pengairan/irigasi).

Fakta di atas berbanding terbalik dengan yang terjadi pada umat Islam Indonesia. Mereka di samping harus membayar pajak kepada negara yang meliputi pajak bumi dan bangunan, pajak barang perniagaan, pajak konsumsi barang, fiskal kalau bepergian ke luar negeri, pajak penghasilan dan lain-lain, mereka juga harus membayar zakat yang meliputi zakat fitrah dan mal. Dengan demikian, umat Islam Indonesia harus memikul double taxs, pajak ganda yaitu zakat dan pajak. Pertanyaannya kemudian adalah bisakah pembayaran zakat sudah dianggap pembayaran pajak atau minimal bisakah pembayaran zakat mengurangi kewajiban membayar pajak? Kalau boleh, apakah kemudian zakat yang dianggap sebagai pajak atau dapat mengurangi pajak bisa diperuntukkan kepada non-Muslim?. Kegelisahan akademik inilah yang dirasakan oleh salah satu intelektual Muslim Indonesia, Masdar Farid Mas'udi. Berangkat dari kegelisahan akademik tersebut Masdar kemudian menuangkan gagasangagasannya yang segar dan bahkan kontroversial terutama tentang isu double taxs. Hal inilah yang coba dianalisa dalam tulisan ini.

\section{Pengertian Zakat dan Pajak}

Kata zakat berasal dari kata zaka yang bermakna menumbuhkan, menambah, memberkatkan, dan menyucikan. ${ }^{1}$ Hasbi ash-Shiddieqy mengutip

*Dosen Fakultas Syariah dan Ekonomi Islam IAIN Walisongo Semarang 
definisi yang dibuat oleh al-Mawardi dan asy-Syaukani. Menurut al-Mawardi, zakat adalah nama bagi pengambilan tertentu dari harta yang tertentu, menurut sifat-sifat yang tertentu untuk diberikan kepada golongan yang tertentu. Sementara asy-Syaukani, menyatakan bahwa zakat ialah memberi suatu bagian dari harta yang sudah sampai nisab kepada orang fakir dan sebagainya, yang tidak bersifat dengan sesuatu halangan syara' yang tidak membolehkan kita memberi kepadanya. ${ }^{2}$

Dengan demikian, menurut ahli fiqh, zakat ialah hak tertentu yang diwajibkan Allah s.w.t. tehadap harta kaum muslimin yang diperuntukkan bagi mereka, yang dalam al-Qur'an disebut mustabik, sebagai tanda syukur kepada Allah, sebagai upaya pendekatan diri padaNya, dan untuk membersihkan hartanya. ${ }^{3}$

Definisi di atas merupakan definisi yang dibuat oleh fuqaha salaf. Dari definisi tersebut dapat dipahami bahwa zakat merupakan kewajiban agama (perintah Tuhan) dalam bidang harta benda. Hanya saja definisi tersebut menyiratkan bahwa peruntukan zakat adalah untuk umat Islam saja atau paling tidak hanya untuk muallaf sebagaimana yang disebutkan al-Qur'an. Definisi ini jelas nanti akan berpengaruh terhadap apakah zakat sama dengan pajak dan karenanya peruntukannya umum tidak hanya bagi umat Islam tapi juga bagi non Muslim.

Pajak adalah kewajiban yang ditetapkan kepada wajib pajak, yang harus disetor kepada negara sesuai ketentuan, tanpa mendapat prestasi kembali dari negara dan hasilnya digunakan untuk kepentingan-kepentingan umum di satu pihak dan untuk merealisir sebagian tujuan ekonomi, sosial, politik dan tujuantujuan lain yang ingin dicapai oleh negara pada sisi yang lain. ${ }^{4}$

\footnotetext{
${ }^{1}$ Mahmud Syalthut, Min Taujihat al-Islam, cet. II, (Kairo: Dar al-Ma'arif, 1972), hlm. 106.

${ }^{2}$ Hasbi ash-Shiddieqy, Pedoman Zakeat, (Jakarta: Bulan Bintang, 1984), hlm. 26.

3 Yusuf Qardawi, Hukum Zakat, terj. Salman Harun, Didin Hafidhuddin, Hasanuddin, (Bogor: Pustaka Litera AntarNusa, 2007), hlm. 999.

${ }^{4}$ Ibid.
} 


\section{Persamaan dan Perbedaan Zakat dan Pajak}

Persamaan zakat dan pajak adalah sebagai berikut: ${ }^{5}$

1. Unsur paksaan dalam menunaikannya.

2. Ada lembaga sebagai pengumpul; pada pajak ada negara dan pada zakat lembaga amil.

3. Tidak mendapatkan imbalan sebagai akibat dari mengeluarkan sebagian harta

4. Sama-sama memiliki tujuan sosial

5. sama-sama memiliki implikasi sosial

Perbedaannya adalah sebagai berikut:

1. Dari aspek nama dan etikanya

Zakat, dari segi tinjauan lafdzi, menunjukkan bahwa dikeluarkannya zakat diyakini akan memiliki implikasi pada kesucian harta, dan menjadi sebab bertambahnya nilai harta. Pajak, dari segi tinjauan lafdzi (bahasa Arab dharibah), menunjukkan bahwa pembayaran pajak berarti melakukan pembayaran upeti. Pada diri seseorang yang telah membayar pajak tidak ada lagi beban upeti.

2. Dari aspek hakekat

Zakat ditunaikan dalam rangka memenuhi tuntutan Allah s.w.t., ia dibayar untuk tujuan ibadah, mendekatkan diri pada Allah dan dalam rangka mencari keridlaan-Nya atas harta yang dikonsumsi, sedangkan pajak dibayar tidak didasari atas keyakinan akan beribadah dan pendekatan diri pada Allah, ia dibayar semata-mata memenuhi kewajiban yang ditetapkan negara.

3. Dari aspek kadar harta

Zakat merupakan kewajiban yang ditetapkan oleh Allah, maka segala ketentuan termasuk jumlahnya Allah-lah yang berwenang untuk menentukan. Tak seorangpun dapat merubah ketentuan-Nya, sedangkan pajak merupakan kewajiban dari negara, maka negaralah yang memiliki kewenangan menentukan jumlahnya, temasuk negara pula yang mempunyai kewenangan untuk menghapuskannya

${ }^{5}$ Ibid., hlm. 999-1000. 
4. Dari aspek kelestarian dan sasarannya

Zakat adalah kewajiban yang bersifat tetap dan terus menerus. Sasarannya sudah pasti ditetapkan oleh Allah, sedangkan kewajiban pajak sangat tergantung pada negara. Sasarannya pun ditentukan oleh negara.

5. Dari aspek pengeluarannya

Sasaran zakat khusus yang ditetapkan Allah dalam al-Qur'an dan dijelaskan oleh Rasulullah saw. dalam sunnahnya, sedangkan pajak dikeluarkan untuk membiayai pengeluaran-pengeluaran umum negara.

6. Dari aspek keterkaitannya dengan negara

Zakat adalah hubungan antara pembayar zakat dengan Tuhannya. Zakat memiliki keterkaitan dengan pemerintah kalau pemerintahnya Islam atau pemerintahan bukan Islam tapi memiliki badan amil zakat yang bertugas mengumpulkan zakat kaum muslim. Sedangkan pajak jelas selalu berhubungan antara wajib pajak dengan pemerintah.

7. Dari aspek maksud dan tujuannya

Zakat memiliki tujuan spiritual dan moral yang lebih tinggi dari pajak. ${ }^{6}$

\section{Diskursus Double Taxs}

Di Indonesia, umat Islam wajib membayar zakat sebagai kewajiban agama, dan karena juga merupakan warga negara Indonesia dia wajib membayar pajak. Kewajiban ini bisa dilihat dari adanya UU No. 38 tahun 1999 tentang Pengelolaan Zakat dan UU No. 17 Tahun 2000 tentang Pajak Penghasilan. Di dalam kedua UU ini dinyatakan bahwa zakat dan pajak merupakan kewajiban. ${ }^{7}$

Sebagai seorang muslim, umat Islam Indonesia harus membayar segala jenis zakat yang memang sudah memenuhi syarat dan rukunnya, misalnya zakat fitrah dan zakat mal. Sebagai warga negara, ia dikenakan PPh (pajak penghasilan), PPN (pajak pertambahan nilai) dikarenakan ia mengkonsumsi barang/jasa tertentu yang menurut pemerintah bukan kebutuhan pokok, seperti komputer, tiket pesawat, air mineral dalam kemasan. Belum lagi dia harus dikenakan PBB (pajak bumi dan bangunan) karena memiliki tanah dan rumah.

${ }^{6}$ Ibid., hlm. 1000-1005.

${ }^{7}$ Gusfahmi, Pajak Menurut Syariah, (Jakarta: PT. RajaGrafindo Persada, 2007), hlm. 7-8. 
Kondisi seperti ini dirasa tidak adil dikarenakan zakat tidak dianggap sama dengan pajak atau paling tidak zakat bisa mengurangi kewajiban pembayaran pajak. Sementara dari aspek politik, umat Islam merupakan penghuni mayoritas di negeri ini. Lebih celaka lagi, ketika pajak yang dipungut dari mayoritas umat Islam ini ketika didistribusikan justru yang paling besar memanfaatkan adalah para pengusaha yang mayoritas non Muslim.

Pandangan seperti ini terkesan eksklusif, tapi itulah demokrasi rumusnya dalam politik adalah one man one vote, mayoritaslah yang seharusnya memegang kendali. Yang penting protes seperti ini tidak kemudian memperlakukan non muslim secara tidak adil/dholim.

Problem di atas dapat dilihat secara kritis oleh Masdar Farid Mas'udi, oleh sebab itu, dalam bahasa Abdurrahman Wahid, ia mengusulkan penafsiran ulang yang tuntas terhadap salah satu rukun Islam yang lima, yaitu zakat. Ijtihad baru Masdar mengajak umat Islam bahkan manusia secara keseluruhan untuk benar-benar menegakkan amanat kekhalifahannya, yaitu dengan menegakkan keadilan dalam kehidupan sosialnya, dan zakat menurutnya adalah pintu masuknya. Masdar membongkar persoalan-persoalan zakat dari timbunan puing-puing kesejerahannya. ${ }^{8}$ Berikut poin-poin yang dibahasnya secara kritis dengan menggunakan bahasa yang provokatif.

\section{Sejarah pranata pajak dalam Islam}

Menurut Masdar Farid Mas'udi, sepanjang sejarah terdapat tiga konsep makna yang pernah diberikan kepada pranata pajak, yaitu 1) pajak dengan konsep upeti (udlhiyyah), kedua dengan konsep kontra prestasi (jizyah), dan ketiga dengan konsep ruh zakat. Konsep pajak yang pertama terjadi pada zaman feodal raja-raja. Dalam konsep pertama ini, pajak (upeti) yang diambil dari darah dan keringat rakyat sepenuhnya adalah milik penguasa yang tidak terganggu gugat, penggunaannya untuk apa, untuk siapa, caranya bagaimana sepenuhnya terserah pada kemauan yang berkuasa. Rakyat tidak memiliki bargaining position sama sekali. Eksploitasi para raja-penguasa terhadap rakyatnya ini berjalan mulus seiring dengan back up para pujangga dan kaum agamawan. ${ }^{9}$

\footnotetext{
${ }^{8}$ Abdurrahman Wahid, "Kata Pengantar" dalam Masdar Farid Mas'udi, Agama Keadilan Risalah Zakat (Pajak) dalam Islam, (Jakarta: Pustaka Firdaus, 1991), hlm. x.

9 Masdar Farid Mas'udi, "Zakat: Etika Pajak dan Belanja Negara Untuk Rakyat", Makalah pada Seminar Nasional Reformasi Pengelolaan Pajak dan Zakat: Peluang dan Tantangan Terkini, Program Studi Keuangan Islam Fakultas Syari'ah UIN Sunan Kalijaga Yogyakarta, 18 September 2006, hlm. 2.
} 
Di Barat Kristen, para raja menggunakan Perjanjian Baru; Roma 13 ayat 1-7 yang menyatakan bahwa tiap-tiap orang harus takluk kepada pemerintah yang di atasnya, sebab tidak ada pemerintah yang tidak berasal dari Allah. Sebab itu barangsiapa melawan pemerintah, sama halnya ia melawan ketetapan Allah, dan siapa melawannya akan mendatangkan hukuman atas dirinya. Di Islam, konsep udlhiyyah ini dilegitimasi dengan ujaran bahwa penguasa (khalifah) adalah bayang-bayang Allah di bumi.

Konsep kedua, pajak sebagai kontra prestasi (jizyah). Setelah sekian lama rakyat dibodohi oleh para penguasa, mereka akhirnya sadar, di manamana kemudian terjadi pemberontakan dan bahkan revolusi. Revolusi besar yang pernah terjadi dalam sejarah untuk menyadarkan rakyat bahwa mereka selama ini telah dizalimi oleh para penguasa/raja antara lain revolusi Inggris (1252), revolusi Perancis (1787), dan revolusi Amerika (1775-1781). Rakyat Amerika meneriakkan slogan no taxation without representation. Pajak boleh dipungut oleh negara/pemerintah tetapi negara/pemerintah harus membaya balik kepada rakyat sebagai taxs payers dalam bentuk perlindungan dan pelayanan umum (public services). ${ }^{10}$ Konsep seperti ini mirip dengan konsep jisyah yang dahulu ada pada zaman kekhalifahan Islam. Jiryah adalah pajak yang diberikan oleh non muslim zimmi yang tinggal di negara Islam agar negara Islam memberikan jaminan keamanan kepada mereka.

Namun demikian, menurut Masdar, konsep ini walaupun lebih baik dari konsep yang pertama tetapi bukan tidak menyisakan masalah. Masalah yang dimaksud menurutnya adalah nalar jisyah sebagai sistem makna yang menjiwai pembayaran pajak. Dengan nalar ini, negara-negara modern mendefinisikan sebagai penjual jasa kepada para pembayar pajak (tax payers). ${ }^{11}$ Padahal sebagian besar pembayar pajak adalah orang kaya sementara orang miskin karena kemiskinannya menyebabkan mereka bukan pembayar pajak atau paling tidak pajak yang dibayarkan orang miskin jauh lebih kecil dari pajak yang dibayarkan orang-orang kaya. Kecenderungan ini menyebabkan negara/pemerintah hanya memberikan jasa (baca: distribusi APBN yang sebagian besar diambil dari pajak) kepada

Lihat juga Masdar Farid Mas'udi, Agama Keadilan Risalah Zakat (Pajak) dalam Islam, (Jakarta: Pustaka Firdaus, 1991), hlm. 103-112.

${ }^{10}$ Ibid., hlm. 6.

${ }^{11}$ Ibid., hlm. 7. 
orang-orang kaya, sementara orang miskin cukup hanya dengan menerima tetesan/luapannya, itupun kalau ada. ${ }^{12}$

Akhirnya, Masdar menyarankan agar pajak menggunakan ruh zakat (sedekah karena Allah untuk rakyat). Dengan ruh zakat ini, diharapkan bisa tercipta keadilan sosial. Bukankah zakat diperuntukkan terutama untuk orang fakir dan miskin, pajak seharusnya demikian pula. Konsep pajak dengan ruh zakat inilah yang pernah dipraktekkan nabi ketika memimpin sebuah pemerintahan di Madinah.

Untuk bisa menerapkan konsep pajak dengan ruh zakat tidak boleh ada lagi dualisme yang dikhotomis, pajak dan zakat harus disatukan sebagaimana ruh dengan badan atau jiwa dengan raga. ${ }^{13}$ Keberanian Masdar untuk menyamakan pajak dan zakat, sebagai konsekuensi untuk mengembalikan zakat sebagai ajaran bisa menuwudkan keadilan sosial, menurut penulis bisa dimengerti dan sudah seharusnya dilakukan untuk mengembalikan Islam sebagai agama pembebas bagi umat manusia termasuk pembebas dari kemiskinan dan kezaliman.

Namun demikian, bagi yang tidak memahami kerangka dasar pemikiran Masdar memang akan menyatakan bahwa pendapatnya keliru. Hal ini sebagaimana yang dituding oleh Gusfahmi dalam bukunya Pajak Menurut Syariah. Menurutnya, pendapat Masdar yang menyamakan pajak dan zakat seperti layaknya seperti menyamakan shalat dan sembahyang atau berdo'a di Pura. ${ }^{14}$ Penggunaan qiyas (analogi) oleh Gusfahmi tersebut menunjukkan bahwa dia masih terkungkung dalam pemikiran yang dikhotomis bahwa pajak adalah sesuatu yang bersifat duniawi sementara zakat adalah sesuatu yang bersifat ukhrawi. Untuk memperkuat pendapatnya, Masdar menerjemahkan semua kata "shodaqah/qat" dalam al-Qur'an yang biasanya dimaknai zakat dengan makna pajak. Beberapa surat/ayat dalam al-Qur'an tersebut antara lain: ${ }^{15}$

a. Surat at-Taubat (9): 104 yang berbunyi:

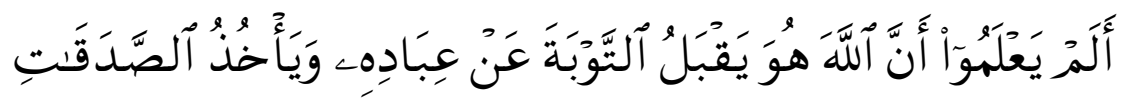

${ }^{12}$ Dalam teori ekonomi, kebijakan yang seperti ini disebut dengan trickle down effect.

13 Masdar Farid Mas'udi, Agama Keadilan..., hlm. 117.

${ }^{14}$ Gusfahmi, Pajak..., hlm. 218.

${ }^{15}$ Masdar Farid Mas'udi, "Zakat: Etika..., hlm. 8-9. 
Masdar menerjemahkan dengan: "Tidak sadarkah mereka bahwa yang berhak menerima taubat manusia hanyalah Allah (bukan para pendeta), juga yang berhak memungut pajaknya (bukan para raja!)"

b. Surat at-Taubat (9): 103 yang berbunyi:

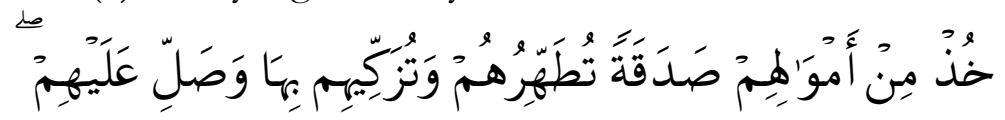

Masdar menerjemahkan dengan: "ambillah oleh-mu (Muhammad, selaku pemerintah) sedekah (pajak) untuk membersihkan mereka dan mengembangkan kehidupan mereka..."

c. Surat at-Taubat (9): 60 yang berbunyi:

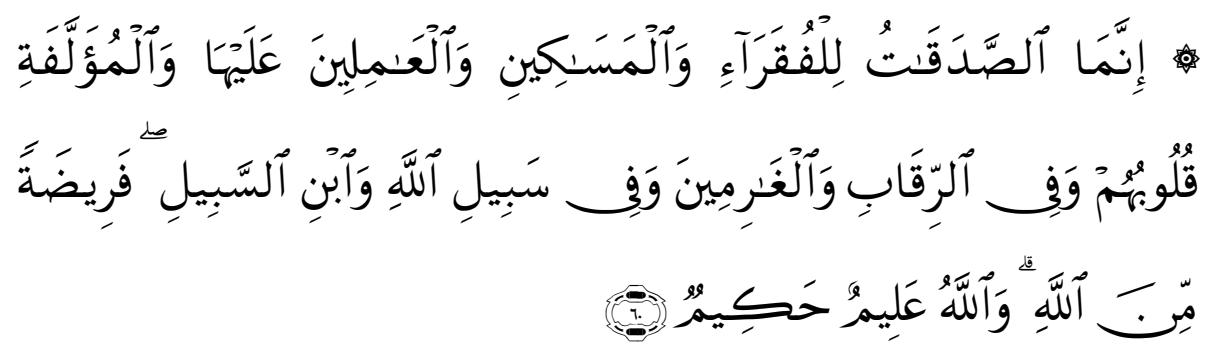

Masdar menerjemahkan dengan: Sungguh, segala macam pajak adalah untuk: i) kaum fakir; ii) kaum miskin; iii) amilin atau petugas pemungut dan pengelola; iv) orang-orang yang disadarkan hatinya; v) untuk kepentingan orang-orang yang tertindas; vi), orang-orang yang tertindih hutang; vii) untuk kebaikan umum; viii) dan untuk keperluan anak-anak jalanan. Itulah kepastian Tuhan. Dan tuhan adalah dzat yang maha tahu lagi maha bijaksana.

Mengenai objek pajak/zakat (mal zakawr), Masdar berpendapat bahwa Nabi (syari') hanya menetapkan objek pajak/zakat yang sekunder, yaitu jiwa dan semua jenis harta kekayaan yang dimiliki oleh masyarakat dimana pajak/zakat ditetapkan yakni pada abad ke-7.16 Dengan demikian, untuk konteks modern banyak sekali kegiatan-kegiatan perekonomian yang tidak disebutkan oleh Nabi dan bukan berarti itu tidak wajib dizakati/pajaki. Jikalau hal-hal baru ini sudah ada pada masa Nabi tentu hal-hal itu dikenakan zakat/pajaknya.

Tak kalah pentingya juga pendapat Masdar mengenai tarif (miqdar) pajak/zakat. Menurutnya, Nabi dalam menetapkan tarif pajak/zakat

${ }^{16}$ Masdar Farid Mas'udi, Agama Keadilan..., hlm. 137. 
adalah berdasarkan berat ringannya tantangan keadilan dan kesejahteraan yang dihadapi. Tarif pajak/zakat pada masa rasul antara 2,5-10\% kecuali rikaz (harta karun) yang sampai $20 \%$ dikarenakan upaya memperolehnya gampang. Jadi tarif 2,5-10\% menurut Masdar dikarenakan 1) faktor kebutuhan yang pada waktu itu masih sederhana. Artinya dengan pengenaan pajak/zakat segitu sudah dapat mencukupi kebutuhan anggaran belanja negara Islam. 2) faktor kesenjangan sosial ekonomi antara si kaya dan si miskin pada masa itu belum terlalu jauh. ${ }^{17}$

Pada masa Nabi sektor perekonomian yang sangat dominan dan menimbulkan kesenjangan di antara masyarakat Madinah adalah sektor pertanian. Oleh sebab itu, tarif pajak/zakat pertanian lebih besar yakni 5\% daripada tarif pajak/zakat niaga yang hanya sebesar 2,5\%. Dengan demikian, kalau sektor yang dominan dan menimbulkan kesenjangan masyarakat juga berubah idealnya tarif pajak/zakat juga bisa berubah.

Pandangan Masdar mengenai pengguna (masharif) pajak/zakat juga sangat menarik untuk dikaji. Dengan penafsirannya yang 'baru' Masdar membuat al-Qur'an benar-benar solih likulli zaman wa makan. Ketika pajak disamakan dengan zakat atau pajak dengan ruh zakat, maka jelas pihak yang berhak menerima alokasi pajak tersebut adalah orang-orang yang secara ekonomi justru tidak mampu, hanya ada dua pihak yang bisa dikategorikan mampu yakni amilin dan sabilillah. Dengan kata lain, mereka adalah orang yang paling sedikit membayar pajak, tetapi paling berhak menerima alokasi distribusinya. Hal ini tidak akan mungkin terjadi kalau konsep pajak yang masih dipakai adalah jizyah (kontra prestasi) lebih-lebih konsep udlhiyyah.

Untuk menyesuaikan makna ayat al-Qur'an dengan konteks kekinian, Masdar menafsirkan muallaf qulububum sebagai orang-orang yang disadarkan hatinya, karena menurutnya, pada dasarnya Rasulullah menafsiri 'muallaf' sebagai orang yang perlu disadarkan hatinya untuk kembali pada jalan fitrah kemanusiaannya. Yang dimaksud dengan 'muallaf' dalam era sekarang ini menurut Masdar adalah a) orang-orang penghuni lembaga pemasyarakatan yang terperosok ke dalam tindak asusila dan atau kejahatan, criminal, b) orang-orang atau anak-anak yang terlibat penggunaan narkoba dan sejenisnya, c) pengembangan masyarakat

${ }^{17}$ Ibid., hlm. 139-142. 
atau suku-suku terasing, dan d) usaha-usaha rehabilitasi kemanusiaan lainnya. ${ }^{18}$

Sementara riqab ditafsiri sebagai orang-orang yang tertindas dan kehilangan haknya. Contohnya buruh-buruh rendahan, buruh-buruh kasar, narapidana politik, tenaga kerja yang dieksploitasi majikannya dan lain-lain. Sedangkan gharimin dimaknai sebagai orang-orang yang tertindih hutang, bahkan dalam konteks yang lebih global, pajak dengan konsep ruh zakat bisa digunakan untuk membayarkan hutang yang melilit negara-negara miskin. ${ }^{19}$

Sabilillah menurut Masdar adalah kebaikan umum, masuk dalam wilayah ini antara lain: a) penyelenggaraan system kenegaraan atau pemerintahan, b) perlindungan keamanan warga negara/masyarakat dari kekuatan-kekuatan destruktif yang melawan hak-hak kemanusiaan dda kewarganegaraan yang sah, c) penegakan keadilan hukum bagi warga negara, d) pembangunan dan pemeliharaan sarana dan prasarana umum seperti jalan, jembatan, sarana komunikasi dan lain-lain, e) peningkatan kualitas manusia/pendidikan, f) usaha-usaha lain yang secara konsisten ditujukan untuk mewujudkan cita keadilan sosial da kesejahteraan umat manusia. Sedangkan Ibnu Sabil, menurut Masdar, adalah anak-anak jalanan, termasuk di dalamnya adalah anak-anak difable yang tinggal di panti-panti. ${ }^{20}$

\section{Double Taxs dalam konteks umat Islam Indonesia}

Kaum muslim sebagai jumlah penduduk terbesar di Indonesia $(87 \%)$ otomatis menjadi subjek pembayar pajak terbesar pula, sementara kalau dilihat distribusi/penggunaan pajak di Indonesia pada tahun 2005 misalnya yang diperuntukkan untuk orang miskin melalui Departemen Sosial hanya sebesar Rp. 16,2 triliun atau setara dengan 4,1\% dari total APBN 2005. Sementara pajak yang digunakan untuk pembayaran cicilan hutang adalah sebesar Rp. 137,9 triliun atau setara dengan 51\% dari total APBN 2005. ${ }^{21}$ Dengan demikian, pajak yang diambil dari mayoritas umat Islam ini lebih separoh hanya digunakan untuk pembayaran cicilan hutang yang hutang tersebut lebih banyak dinikmati oleh orang-orang/pejabat

\footnotetext{
${ }^{18}$ Masdar Farid Mas'udi, Agama Keadilan..., hlm. 152-155.

${ }^{19}$ Ibid., hlm. 155-157.

${ }^{20}$ Ibid., hlm. 157-162.

${ }^{21}$ Gusfahmi, Pajak..., hlm. 8-9.
} 
yang kaya, sementara orang miskin yang sebagian besarnya adalah kaum Muslim hanya mendapatkan tetesan sebesar 4,1 persen (trickle down effect). Ini sungguh dirasakan tidak adil.

Untuk melihat apakah umat Islam Indonesia benar-benar memikul beban ganda (double burden) dalam pembayaran pajak, maka dapat dilihat dari objek pajak di Indonesia. Pertama adalah Pajak Penghasilan (PPh). Objeknya adalah: setiap tambahan kemampuan ekonomis yang diterima atau diperoleh wajib pajak, baik yang berasal dai Indonesia maupun dari luar Indonesia, yang dapat dipakai untuk konsumsi atau untuk menambah kekayaan wajib pajak yang bersangkutan, dengan nama dan dalam bentuk apapun. Hal ini bisa meliputi gaji, upah, tunjangan, honorarium, komisi, bonus, gratifikasi, uang pensiun, hadiah, penghargaan, laba usaha, keuntungan karena penjualan atau karena pengalihan harta, bunga, deviden, royalty, sewa, premi asuransi dan lain sebagainya. ${ }^{22}$

Kalau dilihat secara cermat objek Pajak Pengasilan ( $\mathrm{PPh}$ ) juga merupakan objek zakat, sementara subjeknya di dalam undang-undang tidak dibedakan antara yang Muslim maupun non-Muslim. Dengan demikian, maka umat Islam harus membayar pajak penghasilan dan juga membayar zakat dari objek yang sama.

Objek Pajak Pertambahan Nilai dapat dikelompokkan ke dalam dua macam, yaitu: pertama Barang Kena Pajak (BKP) dan dua Jasa Kena Pajak (JKP). ${ }^{23}$ Tarif pajak untuk seluruh jenis barang atau jasa kena pajak yaitu sebesar 10 persen. Pengenaan tarif yang sama untuk semua jenis komoditi ini menyebabkan golongan masyarakat berpenghasilan rendah terkena proporsi beban pajak yang sama atau bahkan lebih tinggi dibandingkan dengan golongan berpenghasilan tinggi. Dengan demikian, maka telah terjadi ketidakadilan. Di samping itu, umat Islam otomatis ketika melakukan aktifitas belanja barang atau jasa kena pajak wajib membayar pajaknya.

Pajak Bumi dan Bangunan (PBB) adalah pajak yang dikenakan terhadap bumi dan/atau bangunan berdasarkan Undang-undang Nomor 12 Tahun 1985 tentang Pajak Bumi dan Bangunan yang telah diubah dengan Undang-undang Nomor 20 Tahun 2000. Semua umat Islam yang tinggal di Indonesia yang memiliki tanah dan atau bangunan tempat tinggal harus membayar pajaknya kepada negara.

22 Pasal 4 Undang-undang No. 17 Tahun 2000 tentang Pajak Penghasilan (PPh)

${ }^{23}$ Undang-undang No. 18 Tahun 2000 tentang Pajak Pertambahan Nilai (PPN) 
Berdasarkan uraian di atas jelaslah bahwa umat Islam Indonesia sebagai bagian dari penduduk Indonesia, mereka harus membayar semua jenis pajak (PPh, PPN, dan PBB), sementara mereka juga harus membayar zakat jiwa (zakat fitrah) dan zakat mal. Dengan demikian, umat Islam Indonesia dikenai double taxs atau double burden yakni keharusan membayar pajak dan juga keharusan membayar zakat, sementara orang non-Muslim hanya dikenai pembayaran pajak kepada negara saja. Ketidakadilan ini diperparah dengan distribusi pajak kepada fakir miskin yang notabene mayoritas Muslim yang hanya 4,1 persen.

Pandangan seperti di atas terkesan sektarian dan primordial, tapi itulah realitas sosial yang harus dihadapi. Menafikan masalah hanya sekedar untuk dikatakan pluralis dan demokratis tidaklah menyelesaikan masalah itu sendiri, harus ada langkah dan kebijakan konkrit. Salah satu pendapat yang dapat menyelesaikan masalah tersebut adalah pendapat Masdar Farid Mas'udi untuk menyamakan pajak dengan zakat. Dengan begitu, orang yang sudah membayar zakat sudah dianggap membayar pajak, begitu pula sebaliknya orang yang sudah membayar pajak sudah dianggap gugur kewajiban zakatnya. Kalau pun langkah seperti ini tidak bisa dijalankan, bisakah pembayaran zakat mengurangi kewajiban pembayaran pajak.

Usulan yang pertama untuk saat ini memang agak sulit dilaksanakan karena masih ada anggapan bahwa kalau pajak disamakan dengan zakat jumlah penerimaan pajak akan menurun dan penerimaan zakat akan meningkat. Padahal pengalaman Malaysia justru menunjukkan yang kebalikannya. Di Malaysia, dengan perlakuan zakat sebagai bagian dari setoran pajak ternyata jumlah penerimaan pajak meningkat dan penerimaan zakat juga. Namun demikian, jalan ke arah itu tidaklah tertutup bahkan dengan keluarnya beberapa undang-undang yang berkaitan dengan pengelolaan zakat hal demikian bukan tidak mungkin akan menjadi kenyataan.

Usulan yang kedua yaitu pembayaran zakat dapat mengurangi kewajiban pembayaran/setoran pajak sudah terlaksana. Zakat atas penghasilan sesuai UU Nomor 36 tahun 2008 sudah boleh dikurangkan dari Penghasilan Kena Pajak atau bisa dianggap sebagai biaya. Tetapi harus ada syaratnya. Zakat atas penghasilan yang dapat dikurangkan (dianggap sebagai biaya) tersebut harus nyata-nyata dibayarkan oleh Wajib Pajak orang pribadi pemeluk agama Islam dan atau Wajib Pajak badan dalam negeri yang dimiliki oleh pemeluk agama Islam kepada badan amil zakat 
atau lembaga amil zakat yang secara resmi sudah diakui, diakreditasi pemerintah dalam hal ini Departemen Agama. Dalam UU Nomor 36 Tahun 2008, Pasal 4 ayat (3) huruf a dan huruf b dijelaskan bahwa zakat dapat dikurangkan dari penghasilan. ${ }^{24}$

Besarnya zakat yang dapat dikurangkan dari Penghasilan Kena Pajak adalah sebesar 2,5\% (dua setengah persen) dari jumlah penghasilan. Pemotongan zakatnya adalah sebelum penghasilan dihitung dengan tarif progresif. Atau dengan kata lain, zakat dikenakan pada penghasilan bruto.

Kemudian di dalam Undang-undang Pajak Nomor 17 Tahun 2000 dikemukan dalam pasal 9 ayat (1) bahwa harta yang dihibahkan bantuan atau sumbangan, dan warisan sebagaimana dimaksud dalam pasal 4 ayat (3) huruf a dan huruf b, kecuali zakat atas penghasilan yang nyata-nyata dibayarkan oleh wajib Pajak orang pribadi pemeluk agama Islam kepada badan amil zakat atau lembaga amil zakat yang dibentuk atau disyahkan oleh pemerintah. ${ }^{25}$ Diktum tersebut secara jelas menyatakan bahwa zakat yang dibayarkan kepada BAZ dan LAZ yang sah menjadi pengurang penghasilan kena pajak. Dengan demikian, sudah terjadi kesesuaian antara Undang-undang Nomor 36 tahun 2008 dan Undang-undang Pajak Nomor 17 Tahun 2000 dalam hal bolehnya pembayaran zakat menjadi pengurang pajak. Meskipun demikian, zakat baru sekedar diakui sebagai biaya tetapi belum menjadi bagian dari pembayaran pajak. Oleh sebab itu, hal ini masih menjadi tuntutan dari umat Islam.

\section{Penutup}

Islam datang pada hakekatnya adalah untuk menegakkan keadilan di tengah-tengah umat manusia. Ketika umat manusia pra Islam sedang dilanda suatu kondisi dimana yang kuat menindas yang lemah, yang kaya mengeksploitir yang miskin, Islam datang dengan ajaran-ajarannya yang revolusioner. Salah satu ajaran tersebut adalah zakat. Zakat pada masa Nabi tidak dimaksudkan lain kecuali sebagai acuan etika sosial untuk penganggaran negara (state budgeting), baik pada sektor pendapatan (pemajakan) maupun pembelanjaannya. Dengan demikian, zakat dan pajak adalah sama pada masa Nabi. Namun demikian, konsep ini lambat laun berubah seiring perkembangan dan perluasan wilayah Islam. Terjadi perbedaan yang dikhotomistis antara

\footnotetext{
${ }^{24}$ www.business news.com. Diakses pada tanggal 15 Oktober 2013.

25 Undang-undang Pajak Nomor 17 Tahun 2000
} 
pajak dan zakat. Pajak dianggap sebagai sesuatu yang bersifat duniawi sementarra zakat bersifat ukhrawi.

Akibat dari pembedaan yang seperti itu, umat Islam di suatu negeri tertentu seperti Indonesia akhirnya dikenakan double taxs (pajak ganda), kewajiban membayar pajak kepada negara dan kewajiban membayar zakat. Problem ini hanya bisa dipecahkan ketika konsep pajak dikembalikan kepada konsep semula, yaitu tidak adanya perbedaan antara pajak dan zakat. Kalau pun ini tidak bisa dilaksanakan sesuai dengan kaidah ushul fiqh ma la yudraku kulluh la yutraku kulluh, sesuatu yang tidak bisa diperoleh seluruhnya dalam hal ini penyatuan pajak dan zakat, maka tidak boleh ditinggalkan secara keseluruhan yaitu tuntutan subsidiernya misalnya pembayaran zakat dapat dijadikan pengurang pembayaran pajak. Yang terakhir ini Alhamdulillah sudah bisa terlaksana. 
Menimbang Pemikiran Masdar Farid Mas'udi tentang Doubel Taxs

\section{DAFTAR PUSTAKA}

Ash-Shiddieqy, Hasbi, Pedoman Zakat, Jakarta: Bulan Bintang, 1984.

Gusfahmi, Pajak Menurut Syariah, Jakarta: PT. RajaGrafindo Persada, 2007.

Mas'udi, Masdar Farid, "Zakat: Etika Pajak dan Belanja Negara Untuk Rakyat", Makalah pada Seminar Nasional Reformasi Pengelolaan Pajak dan Zakat: Peluang dan Tantangan Terkini, Program Studi Keuangan Islam Fakultas Syari'ah UIN Sunan Kalijaga Yogyakarta, 18 September 2006. - Agama Keadilan Risalah Zakat (Pajak) dalam Islam, Jakarta: Pustaka Firdaus, 1991.

Qardawi, Yusuf, Hukum Zakat, terj. Salman Harun, Didin Hafidhuddin, Hasanuddin, Bogor: Pustaka Litera AntarNusa, 2007.

Syalthut, Mahmud, Min Taujihat al-Islam, cet. II, Kairo: Dar al-Ma'arif, 1972.

Undang-undang No. 17 Tahun 2000 tentang Pajak Penghasilan (PPh)

Undang-undang No. 18 Tahun 2000 tentang Pajak Pertambahan Nilai (PPN)

Wahid, Abdurrahman, "Kata Pengantar" dalam Masdar Farid Mas'udi, Agama Keadilan Risalah Zakat (Pajak) dalam Islam, Jakarta: Pustaka Firdaus, 1991. www.business news.com. 